\title{
DISPOSSESSION, CLASS FORMATION, AND THE POLITICAL IMAGINARY OF COLOMBIA'S COFFEE PRODUCERS OVER THE LONGUE DURÉE: BEYOND THE POLANYIAN ANALYTIC
}

\author{
Phillip A. Hough \\ Department of Sociology \\ Florida Atlantic University \\ phough2@fau.edu \\ Jennifer Bair \\ Department of Sociology \\ University of Colorado at Boulder \\ jennifer.bair@colorado.edu
}

\begin{abstract}
For more than a decade, social scientists have been analyzing the implications of the neoliberal turn in development policy and the implications of market-led agrarian reform for agricultural producers in the global South. Among this work is a spate of recent scholarship celebrating a number of flagship movements, such as the Zapatistas in Mexico or the landless movement in Brazil, which are interpreted as efforts by rural communities to resist the threat posed by the commodification of livelihoods and the privatization of natural resources. In this article, we aim to problematize what we diagnose as the "Polanyian analytic" underlying accounts of the current conjuncture which emphasize the imminent potential of neoliberalism to spawn protective counter-movements of the sort described in The Great Transformation. We do so through an analysis of the Unidad Cafetero Nacional (UCN) movement, an organization of Colombian coffee farmers that effectively mobilized large numbers of cafeteros in the 1990s to protest the liberalization of the global coffee market and the decline of state support for the domestic coffee sector. While the UCN may be read as a struggle to resist the dispossession of Colombian coffee farmers, we argue that it represented a particular segment of rural producers who wanted, first and foremost, a restoration of their relatively privileged status within the political economy of Colombian agriculture. Our interpretation of the UCN suggests that whether movements emerge in response to neoliberalism depends on the political imaginaries of the social actors who would create them, and further, that these imaginaries are produced through processes of class formation over the longue durée that shape the meaning of dispossession in particular contexts.
\end{abstract}

\section{INTRODUCTION}

The abrogation of the international coffee agreement's coffee export quota and pricing regulations in 1989 and the subsequent dismantling of the domestic price support system that was administered by the National Federation of Coffee Growers of Colombia (Fedecafé) had a 


\section{JOURNAL OF WORLD-SYSTEMS RESEARCH}

devastating impact on the country's small landowning coffee growers, a class of independent farmers widely depicted throughout the postwar developmental decades to be a bastion of Colombian political stability and social and economic progress (Bergquist 1986; Sánchez 2001; Rettberg 2010). The liberalization of the global coffee trade generated declining returns and increased insecurity for many of these farmers, and in response to the threat that neoliberal reforms posed to their livelihoods, a significant number fought back. Colombian coffee producers organized to form what became known as the Unidad Cafetero Nacional (UCN) movement, a protest organization that effectively mobilized over 100,000 cafetero militants onto the streets of the largest cities in the coffee-growing regions and eventually led a series of national civic shutdowns (paros cívicos) that forced the Colombian government to accept a number of their key demands (Robeldo 1998).

At first glance, the social unrest triggered by the liberalization of Colombia's coffee economy might be interpreted as yet another case of resistance to an intensified neoliberal capitalism. The mobilization of Colombia's cafeteros resemble several other struggles against dispossession that are described in a recent spate of scholarship, of which David Harvey's The New Imperialism is the best known example. These would include the efforts of peasants and agricultural commodity producers elsewhere to maintain access to the land (McMichael 2006; Akram-Lodhi 2007; Desmarais 2007; Walker 2008), those of organized labor to protect collective bargaining rights (Silver 2003; Barchiesi 2007; Lee 2007), and the many examples of popular-civic unrest triggered by the privatization of natural resources and the retrenchment of public services (Hart 2006; Dunn 2007; Spronk and Webber 2007).

In this article, we offer a different reading of the UCN movement - one that engages with the social and historical conditions of the Colombian coffee sector. In doing so, we aim to problematize what we see as a "Polanyian analytic" underlying the interpretations of the current conjuncture offered by Harvey and others, who emphasize the imminent potential of neoliberalism to spawn counter-movements that push back against the commodifying forces of the market. On the one hand, many scholars acknowledge that the sheer variety of such movements, their rootedness in specific lifeworlds, and the cultural and social distances that separate the protagonists make it difficult to see how these myriad struggles might aggregate to a collective, transformational force capable of challenging neoliberal hegemony. At the same time, much of this literature strikes an optimistic tone, especially when describing movements based in the global South that have emerged to resist accumulation by dispossession in rural communities (Swyngedouw 2005; Desmarais 2007; Spronk and Webber 2007).

While we do not mean to dismiss such optimism as necessarily unwarranted, our analysis of the UCN movement suggests that whether movements emerge in response to dispossession depends on the political imaginaries of the social actors who would wage such battles. Further, the political imaginaries that animate struggle cannot be directly inferred from the logic of accumulation that is driving dispossession, nor, contra the Polanyian analytic described below, can they be explained as reflexive efforts to protect society from the devastation wrought by novel forms of commodification. Rather, these imaginaries are produced through processes of class formation over the longue durée that shape the form and meaning of dispossession in particular contexts, as well as the kinds of struggles that do or do not emerge in response to it. 
DISPOSSESSION, CLASS FORMATION, AND THE POLITICAL IMAGINARY 32

\section{STRUGGLES AGAINST DISPOSSESSION AND POLANYIAN COUNTER- MOVEMENTS}

Recent years have witnessed an upsurge of studies documenting struggles against the shift towards neoliberal economic policies and practices. While this work extends across multiple fields, detailing a variety of struggles in numerous countries and regions, much of it draws theoretical inspiration from David Harvey's interpretation of Marx's concept of primitive accumulation, which he recasts as accumulation by dispossession. In The New Imperialism, Harvey (2003) advances two main lines of argument, and the concept of dispossession by accumulation is critical for each. First, Harvey links the expanded role of accumulation by dispossession during the waning decades of the twentieth century to the sustained period of crisis in the capitalist world economy dating from the collapse of Fordism. In this case, as has been the case throughout its history, "capitalism...requires a fund of assets outside of itself if it is to confront and circumvent pressures of overaccumulation. If those assets, such as empty land or new raw material sources, do not lie to hand, then capitalism must somehow produce them" (Harvey 2003:143). One way that capitalism can produce the assets it needs is to dispossess their current holders of them. It is in this sense, Harvey argues, that dispossession "breathes new life into capital accumulation" (151). Although it turns out that dispossession via privatization, liberalization, deregulation, and above all financialization have failed to reignite robust growth in the world economy, the neoliberal turn has proven far more successful in redistributing wealth, as episodes of dispossession transfer assets from their previous holders, especially the lower classes, to elites (Harvey 2007).

Harvey's second main point follows from this claim about the centrality of dispossession in the current conjuncture: the threat that neoliberalism poses to the material well-being and cultural integrity of working people and their communities is spawning a "swath of oppositional movements," which open up novel and potentially transformative "lines of social and political struggle" (Harvey 2007:40). Thus while neoliberalism creates new forms of deprivation and exclusion, it also engenders new political openings, as suggested by the proliferation of movements that have emerged to resist it. Harvey observes that only occasionally are these movements organized around the workplace or the work relation - that is, around the wage-labor relationship that is both the foundation of "normal accumulation" (or expanded reproduction) and the central axis of contention in historical struggles by labor to intervene in the process of capital accumulation. Rather than focus on the workplace or even the economy as the site of contention, anti-neoliberal or global justice politics tend to target processes of dispossession occurring in the sphere of reproduction. Such struggles, often motivated by identities and commitments that differ from traditional class-based forms of political mobilization, have greater potential for developing politically inclusive and broad-based forms of resistance because they are grounded in the daily efforts of individuals, families, and communities to ensure their social reproduction.

Harvey's powerful indictment of neoliberalism has proven particularly influential among critics of neoliberalism. And his interpretation of the current conjuncture as a political-economic regime that is simultaneously generating increased insecurity and hardship for many alongside new forms of resistance is widely shared by scholars of globalization. While Harvey turns to Marx, other social scientists, and particularly sociologists seeking to understand the causes and consequences of the neoliberal turn, are revisiting the work of Karl Polanyi (1966) in order to draw parallels between the discovery of the self-regulating market in $19^{\text {th }}$-century Europe and the 


\section{JOURNAL OF WORLD-SYSTEMS RESEARCH}

new market fundamentalism of the late $20^{\text {th }}$ and early $21^{\text {st }}$ centuries (Munck 2002; Silver and Arrighi 2003). Here, too, the consensus is that the commodification of social provisioning and natural resources is proving devastating to working people and the environment, but that this second great transformation is unleashing counter-movements that push back against the market forces imperiling the social fabric (Mittelman 1998; Evans 2008).

In a recent article reflecting on contemporary labor studies, Michael Burawoy both notes the prominence of The Great Transformation as an analytical template for making sense of the challenges and opportunities confronting workers and workers' movements in the neoliberal era, and takes issue with what he sees as a common refrain emerging from this scholarship regarding the political potential of laborist counter-movements. Social scientists influenced by Polanyi often refer to the pendulum-like dynamic of historical transformation that he described, whereby efforts to instantiate market relations in place of extant forms of social organization provoke resistance from forces opposing the conversion of land, labor and money into fictitious commodities. But Burawoy cautions against extrapolating from Polanyi's analysis of the first great transformation to the present; specifically, he argues that we should not expect that today's wave of marketization will be similarly met by a counter-movement capable of rolling back the tide of commodification. This interpretation amounts to a misguided optimism that ignores a qualitative difference between contemporary capitalism and the emergence of the market society analyzed by Polanyi, which is that neoliberalism is global in scope. Consequently, any movement to counter it "must begin at the global level for it is only at that level that it is possible to contest the destruction of nature, let alone tackle the global machinations of finance capital" (2010:311). Yet while Burawoy concludes that "[s]ome sort of global countermovement may be necessary for human survival,...there is no historical necessity for it to appear" (311).

It is possible to draw an analogy between the "uncompromising pessimism" with which Burawoy confronts the "Polanyian Pollyannas" of labor studies, and the concerns that David Harvey expresses in The New Imperialism regarding the possibility of political challenges to neoliberalism. Burawoy's concern is that laborist counter-movements that are rooted in the experience of exploitation - what Harvey calls accumulation by expanded reproduction - are an inauspicious foundation for challenging the increasingly common and more salient experience of capitalism, which is commodification. When the normative status of regularized, waged employment is under assault by new and generally less secure forms of work, politics that center around exploitation resonate less than those that focus on commodification, with the latter "potentially bringing together not only wage labor and the great swaths of informal, precarious labor, but also joining them to movements against the commodification of nature, of money, and indeed of knowledge" (Burawoy 2010:75). Burawoy's counter-movements against commodification are similar to Harvey's struggles against accumulation by dispossession, and although Harvey considers it an urgent task to recognize the relationship between, and forge connections among, these struggles and those against expanded reproduction, he too seems more optimistic about the transformative potential of struggles against dispossession as compared with struggles against expanded reproduction (cf. Silver 2003).

This optimism is perhaps reflected most strongly in studies of rural communities that are experiencing dispossession in the form of land privatization and other forms of agrarian restructuring that threaten agricultural livelihoods. Chief among these are the Movimento dos Trabalhadores Rurais Sem Terra (Landless Workers' Movement) in Brazil (Ondetti 2006), the Ejército Zapatista de Liberación Nacional (Zapatista Army of National Liberation) in Mexico (Harvey 1998; Vergara-Camus 2009), and the transnational peasants' movement Via Campesina 
(Desmarais 2002; McMichael 2008). While scholars writing about agrarian movements acknowledge that rural communities are responding in a variety of ways to the challenges that neoliberalism poses to their prosperity, autonomy, and even ontological security, an optimistic tone runs through much of this literature; indeed, this tone is similar to the one that Burawoy decries in the labor studies literature, with some authors making explicit the Polanyian lens through which they view developments in the countryside (McMichael 2008; Gimenez and Shattuck 2011).

In the remainder of this paper, we consider one community of producers impacted by farreaching changes in the political economy of agriculture over the past four decades. The liberalization of the global coffee market and the collapse of the developmentalist compromise between the Colombian government and the country's smallholders ${ }^{1}$ that the regulation of that market had permitted has ushered in a wave of dispossession affecting many cafeteros and their communities. While coffee-growers did mobilize in response to these developments in the form of the UCN, they failed to arrest either the deterioration of smallholder livelihoods or the erosion of their collective power as an organized class of producers. Below we explain this outcome by showing how the content of the cafeteros' counter-movement was shaped by a historical process of class formation that tied smallholding coffee farmers into a strategic alliance with the state, and simultaneously assured their structural dependence on the world coffee market.

\section{LAND STRUGGLES, COFFEE PRODUCTION AND DISPOSSESSION IN VIEJO CALDAS $^{2}$}

Colombia's coffee export sector dates back to the 1820s, when large hacienda owners located in the eastern and central Cordillera Mountains began to convert portions of their fields to coffee in order to take advantage of the burgeoning market for coffee in the United States and Europe. It was the government's decision to privatize large tracts of public lands (baldios) in the 1870s, a measure aimed at converting sparsely populated frontier regions into sites of capitalist production, however, that initiated the mass migration of settlers southwards from the department of Antioquia into the slopes of the western Cordillera region of Viejo Caldas. The migrants who settled the region (colonos) included minifundista peasants impoverished by the over-fragmentation of their properties, rural artisans displaced by the importation of cheap foreign manufactures, and Indigenous families dispossessed of their communal lands. They saw the availability of attaining land in the open frontier as a way to gain greater control over the means of their subsistence. However, most chose to settle in regions located nearby rivers, roads, and railroad lines so that they could supplement their subsistence agricultural production by producing commodities for the market, coffee being the most lucrative (LeGrand 1984; Christie 1986).

By the close of the $19^{\text {th }}$ century, coffee had trickled down from being a luxury good consumed by elites to a mainstay of the North American urban-industrial working-class diet (Jiménez 1995a). This escalation in demand provided Colombian producers and exporters with an ideal opportunity to invest in the conversion of ever-greater portions of land to coffee cultivation with minimal risks to runs on their investments. In fact, by the first decade of the $20^{\text {th }}$ century, coffee had become Colombia's chief export commodity. And while coffee production in

\footnotetext{
${ }^{1}$ We use the term "smallholder" to include farmers who own between 5 and 15 hectares of land.

${ }^{2}$ Viejo Caldas (Antigua Caldas) was the original name of the region that later formed into the three political subdivisions (departamentos) of Caldas, Risaralda, and Quindío.
} 


\section{JOURNAL OF WORLD-SYSTEMS RESEARCH}

Viejo Caldas amounted to a mere $4 \%$ of the coffee produced in Colombia, it escalated over the next three decades to roughly $40 \%$ of the total, becoming the largest coffee-producing region of the country (Vallecilla Gordillo 2001: 147).

The possibility of accumulating wealth through coffee production in Viejo Caldas, however, generated conflict between smallholders seeking to supplement their livelihoods through coffee, and large-scale planters seeking to force these colonos off the lands, thereby transforming them into permanent workers whose labor could be exploited on the coffee estates. The estate owners relied upon two key mechanisms of dispossession. First, since the colono settlers could not often afford to pay the surveying and titling fees required for formal title to the land, many ended up squatting on lands that were in fact owned by these elites. When this was the case, the landowners were able to use their influence over local courts and magistrates to legally force the squatters further out into the frontier, where the process would occur once again. However, given the political monopolies they typically held over local state offices, estate owners would also at times forcibly displace smallholders whether they held formal land titles or not. Lacking influence over the courts, many unfortunate title-owning smallholders were left with no other recourse than to leave the land they tilled. Some left to try their fortunes once again by carving out a new tract of farmland deeper in the agricultural frontier. Others, less willing or able to start from scratch once again, submitted to their displacement and became agricultural workers on the coffee estates (LeGrand 1984).

By the first decades of the $20^{\text {th }}$ century, these struggles had produced a variegated landscape of coffee producers. On the one hand, the open frontier in Viejo Caldas facilitated the growth of a sizable number of small and medium-sized coffee smallholders who succeeded in cultivating modest plots of land along the most remote slopes of the western Cordillera. On the other hand, there were numerous large coffee estates worked by sharecroppers and renters (arrendatarios), who were permitted a small plot of land to grow their own subsistence crops in exchange for the payment of a specific amount of coffee beans or a set number of hours dedicated to the production of coffee for the land owners (Bergquist 1986:316-317).

The exponential expansion of the sector as a whole from the 1910s until the 1930s led to a substantial growth in the demand for labor on the coffee estates, which began to hire proletarianized yearly and seasonal workers to supplement tenant farmer and arrendatario labor arrangements. It also saw the emergence of large commission houses based largely in New York and London that purchased coffee from the estates (and smallholders) through local merchants and provided credit to the estate owners to finance the salaries of their workforces and subsidize the expansion of their plantations (Jiménez 1995b). The rise in prices during the middle years of the 1920s in particular emboldened the estate workers, who began to pressure the owners to liberalize the terms of their contracts so that they could convert greater portions of their own plots to the cultivation of coffee. As Bergquist (1986:334-336) notes, the estate owners were both willing and able to make these concessions because credit remained easy to attain and because the expansion of arrendatario payments of coffee ultimately bolstered the estate's overall productivity without cutting into the owners' profit margins. The smallholding farmers, for their part, also began converting ever greater portions of their own lands to coffee for the same set of reasons; the growing demand for coffee by workers and elites in the global North had created the possibility for smallholders, workers and estate owners in Colombia to milk this cash cow, despite the fact that it entailed a further marketization of their livelihoods.

The stock market crash of 1929 and the subsequent drop in world coffee prices that followed dramatically shaped the historical trajectory of the region. To be sure, the crash in 
prices did not fundamentally alter the nature of production on the small and medium-sized coffee farms of Viejo Caldas because these smallholding producers could internalize the costs by drawing upon family labor forces to convert their coffee lands back to subsistence agricultural production. The fact that they remained in control of the productive use of the land, formal title or not, granted them the possibility to move into as well as out of the market for coffee on more or less their own terms (Machado 1977).

The impact of the Great Depression on the large estate holders, in contrast, was catastrophic. The sudden drop in coffee prices propelled many planters into bankruptcy and debt to the commission houses. Many attempted to avoid ruin by externalizing costs onto their workers, squeezing more labor out of them for the same pay. This proved a daunting task because over the course of the 1920s the workers on these estates had become highly organized and increasingly militant under the leadership of communist and socialist activists. As mentioned above, the efforts of workers to liberalize the terms of their tenancy and labor agreements had been tolerated by estate owners during better times because the demand for coffee was strong enough to accommodate an increase in local supply. When the crunch in the world coffee market made itself felt, estate owners attempted to compensate by reversing those arrangements. The estate workers, however, had grown accustomed to using their land in this way. Moreover, the fact that they could internalize the drop in prices (by mobilizing the collective labor power of their families) without reducing the volumes of coffee grown gave weight to their claims that they could make better use of the land than the owners themselves.

Estate owners were further discomfited by the views being expressed by some officials within the Colombian government, who were flirting with economic planning as a way to confront the crisis. Sensing a dual threat of state appropriation and worker takeover, they began exploring ways to break their contracts with the arrendatarios in order to legally expulse them from the lands as a preventative measure. Rather than simply forfeit their plots to the estate owners, however, the workers began to follow the example of the frontier smallholders by simply squatting on the lands that they were already working and occupying. The estate owners countered this militancy by using their control over local politics to violently force the workers from estate lands using police and hired thugs (Machado 1977; Bergquist 1986: 339-343).

The outbreak of violence and terror that emerged on the coffee estates became a hot political issue in the presidential election of 1930, with the Conservative Party supporting the coffee planters and the Liberals advocating for land reforms. The election went to the reformminded Liberal Carlos Lleras Restrepo who feared that the agrarian unrest would destroy the coffee export sector altogether. In order to end the crisis and save the coffee industry, Lleras Restrepo signed Land Law 200 of 1936, which facilitated governmental purchases of the bankrupt estates, subsidized the sale of parcels of these estates to the squatters that occupied them, and granted formal land titles to the smallholding squatters along the coffee frontiers. The Law was therefore able to forge a consensus between key players within the political establishment. Conservatives backed the government's agreement to pay full market prices to estate owners for the appropriated land. Liberals were content to have the land out to productive use. And militants of the Communist Party were content with the transfer of land to the squatters. With this compromise came an effective end to the largest agrarian struggle of Colombian history. 


\section{JOURNAL OF WORLD-SYSTEMS RESEARCH}

\section{SMALLHOLDERS AND FEDECAFÉ DEVELOPMENTALISM IN VIEJO CALDAS}

The passage of Land Law 200 might have restored control over the means of subsistence to Colombia's smallholders by providing the impetus for a massive conversion of the coffee fields back to subsistence agriculture on the newly formalized parcels. Instead, however, this land reform laid the groundwork for a series of developmentalist initiatives to stimulate the growth of the coffee export sector through the consolidation of a smallholder structure of coffee production. These efforts began in 1927, with the establishment of the National Federation of Coffee Growers of Colombia (Fedecafé), a semi-private parastatal organization of commercial and financial capitalists authorized to organize and vertically-integrate the nation's coffee industry. Fedecafé was granted the right to tax and regulate the sector through the creation of the National Coffee Fund (FNC) in 1940, which financed the establishment of a system of coffee storage and husking plants (trilladoras) throughout the diffuse geography of coffee fields. The FNC instituted a garantia de compra policy that guaranteed the purchase of smallholder beans that met quality standards set by Fedecafé as long as these smallholders became card-carrying members of the local chapter of the Federation. The FNC also subsidized a price floor system to guarantee that the price of beans sold by farmers at their trilladoras would not fall below a level necessary to sustain a typical smallholding family. Moreover, in order to ensure steady yields and productive farms, Fedecafé granted low-interest loans to farmers through their Banco Cafetero (created 1950), as well as regular technical assistance through the development of a broad extensions program attached to a science institute (Cenicafé) that hired a team of international scientists that studied the sector (London 1999).

These investments in the stable social reproduction of the region's coffee producers through provisions of subsidies, credit, and market regulations proved successful in stimulating productivity in Colombia's coffee industry in the period leading up through the years of the Second World War and into the so-called "golden decades" of the post-War period. It is also widely noted that smallholder coffee production, symbolized through the icon of Juan Valdez, became considered a nationalist enterprise bringing wealth, order, and a powerful national identity to the country (London 1999). Many smallholders began to convert larger sections of their land holdings to coffee production, even adopting new seed types that required more mechanized inputs of production, including expensive fertilizers and irrigations systems, and a shift away from shade-grown plants that intertwined coffee with subsistence produce in favor of sun-tolerant plants that yielded more beans per plant but could not be planted alongside other crops. These transformations provided the region's coffee producers with the opportunity to attain greater income to purchase the bulk of their subsistence needs at the risk of further commodifying their livelihoods (Ortiz 1999).

Critical to our narrative is the fact that, to the degree that these initiatives were indeed effective in meeting (or even improving) the standards of living desired by these coffee producers, they also tended to generate bastions of support for the political status quo at the expense of those excluded from the benefits of the developmentalist politics of the state. With few exceptions, the smallholders of Viejo Caldas backed Fedecafé in its unwavering support for the elite-led and highly exclusive Liberal and Conservative Parties that monopolized the country's highest political offices (Bergquist 1986). This support continued during the years of sectarian political violence called La Violencia (1948-1957), the years of military dictatorship 
under General Rojas Pinilla (1953-1957), throughout the years of the National Front regime ${ }^{3}$ (1957-1974), and even following the writing of a new national constitution in 1991.

While the political conservatism of the cafeteros has been hailed by some as a "great transformative and integrating force" responsible for the relative stability of Colombia's political regime (Sánchez 2001:3-4), it also meant that the traditional political establishment could implement radical industrialization and trade liberalization policies that caused social upheaval, over-urbanization, and rapid proletarianization of significant portions of the populace. The support that the cafeteros gave to such policies served as a continual wedge between the coffee smallholders and a larger and increasingly militant population of agricultural workers and peasants outside of the coffee sector, urban students, and industrial workers who were excluded from the benefits of the coffee-based developmental model (Bergquist 1986). The lack of availability of quality land for the majority of Colombia's rural population, the hostile and oppressive working conditions characterizing the export sectors such as oil and bananas, and the former exclusion of third parties from participation in electoral politics gave rise to increasingly radicalized and organized sectors of the labor force. However, the coffee smallholders of Viejo Caldas not only refused to join national struggles for radical land and labor reform measures that emerged in those regions of the country marked by marginalized subsistence peasantries and repressed proletarianized agro-export workers in the 1960s; they also proved impermeable to the sway of revolutionary guerrilla activities that emerged in those same regions in the 1970s once the agrarian movements were effectively repressed by the Colombian state (Zamosc 1986).

\section{NEOLIBERALISM AND THE UNRAVELING OF THE DEVELOPMENTALIST PACT}

The viability of a smallholding system of coffee production in Colombia rested upon Fedecafé's capacity to finance the stable reproduction of these producers, which, in turn, rested upon the state's ability to push competitive market pressures in the world coffee trade upwards via regulation of the world coffee market (Hough 2010). In fact throughout the developmental decades, the Colombian government (through the lobbying efforts of Fedecafé's directorate) coordinated "cartel-like arrangements" with Brazil to secure higher prices by withholding coffee. During the Second World War, this strategy was accepted and institutionalized by the United States as a measure to thwart Axis influence in the hemisphere. Coffee importers and roasters in the United States were pressured to accept lower profit rates and higher coffee prices in order to maintain U.S. geopolitical legitimacy in coffee-producing countries. Similarly, during the years of the Cold War, as part of the Alliance for Progress, the U.S. signed onto a series of International Coffee Agreements (ICAs), which regulated world coffee prices and volumes, thus ushering in a period of protracted price stability and expanded growth for the sector (Krasner 1973; Talbot 2004).

The viability of the ICAs in generating social stability throughout the coffee-producing regions of Latin America, Viejo Caldas included, was no doubt a reflection of U.S. global hegemony in the postwar decades. However, by the 1970s, the success of the ICAs in generating spaces of "upward mobility" and development for coffee-exporting countries had begun to fundamentally challenge U.S. corporate control over the market. Fedecafé, along with Brazil's producer-exporters, began developing its own marketable brands of instant coffees and coffee

\footnotetext{
${ }^{3}$ The National Front was a formal power-sharing agreement wherein the leaders of the Liberal and Conservative Parties agreed to rotate top political posts between them, appoint departmental and local positions by party leaders, and formally exclude the possibility for third parties to run for executive office.
} 


\section{JOURNAL OF WORLD-SYSTEMS RESEARCH}

products that threatened the monopolies held by North American and European roasting and marketing corporations over their national consumer markets. Moreover, the success of coffee production as a model of export-led development convinced other countries throughout the global south to establish their own coffee sectors, some of whom sought a piece of the market through the ICA system, and others who began producing outside of it. While a full elaboration of these struggles over the regulation of the coffee commodity chain is beyond the scope of this article, it is well-documented that by the 1980s U.S. policy had radically shifted away from supporting the ICA system, eventually leading to a political rift amongst participating countries that culminated in the abrogation of the ICAs' quota and pricing system in 1989 (Bates 1997; Talbot 2004).

The termination of the ICA system in 1989 led to an immediate and drastic drop in the world price of Arabica mild coffee beans from almost $\$ 2.50 / 1 \mathrm{~b}$. in 1987 to just over $\$ 0.50 / 1 \mathrm{~b}$. by 1993 (Oxfam 2002). And despite a brief jump in prices in 1994-1995 due to coffee frost and drought in Brazil and in 1997 due to a speculative hike, the average composite price during this time remained 20\% lower than it was during the closing years of the 1980s (Ponte 2001:11-13). Fedecafé responded to this drop by cutting the export taxes collected by the National Coffee Fund and using its accumulated reserves to subsidize growers for their losses. While this lasted for a short period of time, the depletion of these reserves, coupled with the appearance of a coffee berry borer worm (la broca) that spoiled close to 500,000 hectares of coffee fields by 1995, forced the FNC to sell off its interests in the Banco Cafetero and seek out loans from the central government, both to finance the control and extermination of the broca worm and to attempt to continue to subsidize the drop in coffee prices. By the closing years of the decade, the FNC had incurred debts of over $\$ 433.5$ million dollars so that by 2001 it was forced to abandon the price floor mechanism. And without the price floor to assure producers a price pegged to the cost of living locally, the FNC's ability to maintain its garantia de compra policies was also undermined, giving way to increasing competition between Fedecafé and foreign transnational conglomerates (including Kraft, Cargill, Neumann, Volcafé). Between 1989 and 1996, the share of coffee purchased from local producers by these conglomerates rose from roughly $8 \%$ to $52 \%$ of all purchases. With less to sell, Fedecafé's revenues dropped over the course of the decade by 80\% (Robledo 1998: 101-102; Talbot 2004: 128).

While Fedecafé's developmentalist institutions were in shambles, it was the cafeteros who felt the impact most severely. The cost of coffee production skyrocketed at the same time that prices declined, leaving many farmers in debt. In the past, coffee farmers would turn to the Banco Cafetero for low-interest loans and to Fedecafé for technical support and assistance during hard times. However, the bankruptcy of the FNC meant that many farmers were forced to resort to the high-interest loans of private banks that did not have a public mandate to service the specific needs of the cafeteros. By the close of the decade, their indebtedness to private banks reached new heights.

Facing bankruptcy, many smallholders began to sell ever-greater portions of their farms, leading to a concentration in land ownership and a polarization in the size of landholdings throughout the region (Robledo 1998: 71). Some indebted coffee producers continued to cultivate coffee, though in this case as wageworkers on others' coffee estates rather than as landowning farmers. ${ }^{4}$ Other indebted smallholders simply abandoned their fields to look for wage work in the region's three largest cities, contributing to an estimated $8 \%$ per annum

\footnotetext{
${ }^{4}$ One study found a 32\% drop in the number of farmers dedicated "full-time" to coffee cultivation between 1993 and 2001 (World Bank 2002).
} 
increase in informal sector economic activities and an average rate of unemployment of $22 \%$ in the regions' largest cities (Manizales, Pereira, and Armenia) (Ramirez et al. 2002:41). Still others, unwilling to move to the cities or work on large agricultural estates, ended up migrating to the coca-producing regions of the southern agricultural frontiers under the de facto control of the Revolutionary Armed Forces of Colombia (FARC) guerrillas. Here, at least they could maintain their ties to the land, even if it put them at risk of violence and repression from both the FARC as well as from paramilitary groups allied to the Colombian military (Hough 2011a, 2011b). Finally, some began to convert their own coffee fields into coca fields (Smith 2003). This conversion to illegal coca production brought the FARC, paramilitary groups, and organized criminal syndicates into a region that had hitherto been considered impermeable to the crime and political violence characterizing the rest of the country over the past decades (Rettberg 2010).

\section{THE RISE OF THE UCN: A POLANYIAN COUNTER-MOVEMENT?}

It was in this context of bankruptcy, falling prices, and economic instability that the Unidad Cafetero Nacional emerged. Mobilizing a large number of card-carrying cafeteros outside of the normal institutionalized channels provided by Fedecafé (extensions programs, local meetings, departmental and national conferences) was no small feat. In fact, historically independent protest movements were largely absent from the region due to the ability of Fedecafé to meet the demands of cafeteros, following the formation of the FNC in 1940. However, Fedecafe's failure to deliver on its promise of protecting cafetero livelihoods precipitated the unification of two organizations that were marginal in Viejo Caldas prior to the coffee crisis: the Association of Coffee Producers (Aprocafé), an organization of large coffee estate owners formed in 1977 to argue against the "discriminatory treatment" they faced under the FNC's taxation policies, and the Unión Cafetera Colombiana (UCC), a group of small and medium-sized farmers who organized in 1984 to pressure Fedecafé to invest more resources into combating a coffee rust fungus (la roya) that had broken out in the region. Anticipating the impact that the abrogation of the ICAs would have on the FNC, these groups fused under the leadership of Fabio Trujillo Agudelo of Aprocafé and Jorge Enrique Robledo Castillo, a militant from the Movimiento Obrero Independiente Revolucionario (MOIR) political party who had previously organized street protests with a group called Cafeteros en Alerta.

The unification of these two groups under the leadership of Trujillo and Robledo led to the formation of the UCN in 1992. The UCN's goal was to pressure Fedecafé to fulfill its promises to protect the sector and maintain the stable livelihoods of coffee producers. Specifically, the UCN sought an immediate suspension of judicial claims against indebted producers, the refinancing of retirement pensions, and more reasonable interest rates on loans. Its leadership also argued more broadly against the encroachment into the coffee sector by foreign transnational corporations (Robledo 1998: 38).

A number of protests organized by the UCN soon followed. In February of 1992, the first National Coffee March was held. In December a "Day of Coffee Producer Resistance" was organized which resulted in numerous demonstrations throughout the region. By March of 1993, producers from six coffee producing states (departamentos) marched on Bogotá, carrying a letter with UCN demands to President Gaviria. In November, the Bishop of the coffee-producing state of Tolima, Monsignor Jose Luis Serna, organized an Episcopal Conference that called on all coffee producers to organize and defend themselves by demanding the state to forgive their 


\section{JOURNAL OF WORLD-SYSTEMS RESEARCH}

financial debts. From then on, debt forgiveness and open confrontation with the government and Fedecafé became central elements of the burgeoning coffee producer movement (Robledo 1998: 39).

In March 1994, President Gaviria met with the UCN leadership, who presented him with a petition demanding fulfillment of UCN demands and containing over 200,000 signatures. With their demands unmet, the UCN organized a national march that brought producers from 8 coffeeproducing states to Bogotá to declare Gaviria "the most anti-coffee president in the history of Colombia" (Robledo, 1998:40). By March 1995, the UCN was actively organizing in nine departments and had roughly 25,000 active militants who ranged from smaller peasants to larger coffee hacendados. In May of that year, Fedecafé's Comité Nacional de Caféteros approved the forgiveness of $25 \%$ of banking debts (roughly 10 million pesos) and made available $\$ 40$ billion pesos in subsidies to control an outbreak of a coffee berry borer worm (la broca), all of which was subsidized by the FNC (ibid:40).

Unsatisfied with debt forgiveness of only $25 \%$, the UCN decided upon more militant protest tactics. In June of 1995 it organized the first Paro Cívico Cafetero Nacional (national coffee shutdown) in the history of the country. A twenty-four hour protest was held, with over 100,000 people from 151 municipalities and 10 departments participating. Participation was broad-based, as transport workers, local businessmen, teachers, students, and even some local politicians and clergyman joined with the UCN in a show of solidarity. The state responded with Law 223 of 1995, which granted total forgiveness of debts on capital and interests on loans from banks to coffee producers so long as they followed three conditions: (a) if those loans were used for the purchase of productive inputs; (b) if they occurred before December 31 of 1994; and (c) if they did not supersede 3 million pesos. The UCN felt that the 3 million-peso cap on debt forgiveness was not enough, and after a series of protests in 1996, it declared in February 1997 that coffee producers would step up their civil disobedience activities. By the end of year, the FNC finally caved, promising a full forgiveness on debts for 86,783 families (Robledo 1998:4142).

The closing years of the decade brought another onslaught of protests by the UCN, this time due to the rapid expansion of the broca berry worm in the region in 1997, an earthquake in January 1999 that devastated large tracts of coffee fields in the department of Quindío, and the drastic drop in world coffee prices following a brief spike due to frost in Brazil. Given the financial insolvency of the FNC and Fedecafé more generally, the UCN instead turned its protests to the national government, which it argued was ultimately responsible for the protection of the coffee sector and the economic livelihoods of the cafeteros.

In an effort to help save the coffee sector from total collapse, the Colombian government agreed to finance an aid package providing producers with a direct subsidy pegging local prices of coffee to the international market price. They also agreed to help indebted cafeteros refinance their loans and access new loans to cover the cost of technical assistance and the purchase of new coffee trees. In essence, the government agreed to take on the responsibilities previously held by the FNC for a two-year period. In 2003, the FNC reassumed these responsibilities, announcing that the price floor mechanism would remain pegged to world prices, future access to credit would come through the private banking system, and access to technical provisions and extensions services formerly provided by Fedecafé (through Cenicafé) would remain limited (Giovannucci et al. 2002; CONPES 2004:6).

Despite the increasingly radical tactics of the UCN during the years following the abrogation of the ICA and the dismantling of Fedecafé's developmentalist institutions, the UCN 
remained staunchly developmentalist in its orientation. The organization's primary goals were to reinstate a price floor mechanism pegged to local living costs, restore cafetero access to easy credit, and reinstate the extension services and technical support offered by Fedecafé and its auxiliary organizations (FNC, Cenicafé, Banco Cafetero, etc.) in order to maintain a viable regulated coffee export sector that benefited large and small domestic producers alike. The UCN was able to mobilize such strong support from small and medium-sized cafeteros precisely because the group's leaders repeatedly and publicly stated that domestic coffee production was the key pillar of national development. According to this logic, Fedecafé was to blame for the current crisis precisely because it abandoned its commitment to the well-being of the cafeteros. ${ }^{5}$

However, while Fedecafé was criticized by the UCN for failing to support smallholding coffee production, Fedecafé's directorate shared the very developmentalist vision advocated by the UCN. Its directors had been among the staunchest advocates of the International Coffee Agreement's coffee quota and pricing system precisely because the ICA buttressed Fedecafé's own pricing and market subsidy system. Thus, in their general orientations towards the political economy of the coffee sector, there was little difference between the UCN militants and Fedecafé directors. When confronted with UCN demands for the re-establishment of the regulatory market mechanisms of the past, Fedecafé's leadership responded that it would reinstate them if it could, but that the global context had shifted in such a way as to make this impossible. In fact, Fedecafé's directors made it clear that, from their vantage point, all of the actors involved in Colombia's coffee economy were under assault by the new neoliberal politics of United States and the growing power of foreign coffee conglomerates (Hough 2007: 117).

It comes as no surprise then that by the turn of the century, the UCN's leadership had decided that the best hope for a return to the developmentalist compromise of the past would come by joining a broad federation of agricultural producers aimed at opposing any efforts to further liberalize the national agricultural sector. This organization, called the National Association for Agricultural Salvation (Salvación Agropecuaria), is a coalition of more than 50 regional and national groups, including large agribusinesses with interests in sugar cane, potato, and grains, as well as smaller and medium-sized producers. Fedecafé's directorate, for its part, did not become formally involved in the activities of Salvación. Instead, it began to strategize how to best adapt to the shift in the world economic climate, beginning with an attempt to market its new Juan Valdez coffee products directly to consumers in the United States. UCN's leaders, in turn, became further involved with Salvación over time, eventually organizing mass demonstrations against talks of a "Free Trade of the Americas" agreement in 2001, climaxing in a national day of protest in Bogotá in April 2004. By then, the UCN had ceased to exist as its own entity, though some of its militants remained active in Salvación.

\footnotetext{
${ }^{5}$ Sociologist Christopher London conducted research in the region between 1996 and 1998, surveying 446 smallholders in the departments of Caldas and Nariño and holding a series of roundtable discussions with 93 of those surveyed with the intent of finding out what the cafeteros considered to be the causes and potential solutions to the crisis facing the sector. He concluded that the "developmentalist orientation continued to provide the lens through which the growers perceive the crisis and their own place in it" (London 1999: 98, 110). Of those surveyed, $64 \%$ believed that the crisis was "out of their control" and any possible solution would have to come from Fedecafé and/or the central government (ibid 126-127, 134-135).
} 


\section{JOURNAL OF WORLD-SYSTEMS RESEARCH}

\section{DISPOSSESSION AND THE LIMITS OF THE CAFETERO POLITICAL IMAGINARY}

Insofar as the UCN was the clearest representative of Colombia's smallholding coffee sector, claiming to represent the interests of the cafeteros who were struggling to maintain their livelihoods in the context of market liberalization, the organization's trajectory is instructive of the political imaginary shaping cafetero resistance. The UCN was established in large part out of the remnants of Aprocafé, a group that emerged to advocate for the interests of large coffee estate owners against what it argued were discriminatory taxation policies that favored smalland medium-sized farmers. After a period of mobilization targeting Fedecafé and the rest of the Colombian government, the UCN became absorbed into Salvación Agropecuario. At no point in time did the UCN, or Salvación for that matter, articulate a radical alternative to a regime of market-oriented production on privately-owned land; rather, what they sought was a return to the status quo that had prevailed prior to the 1989 collapse of the International Coffee Agreement.

To be sure, this stance may have reflected a tactical choice rather than the contours of the cafetero political imaginary. However, it important to point out that the UCN's decision to forge strong cross-class alliances between small and medium-sized cafeteros and large coffee estate owners around a domestically-oriented developmentalist agenda had a series of political consequences. First, while the UCN employed a nationalist discourse that downplayed differences among coffee farmers, the UCN's agenda was effectively biased towards the largest and most fortunate coffee producers - those who were able to hold out over the course of the decade despite their direct exposure to the whip and whims of the open coffee market. In fact, during the same years that the UCN was mobilizing its members in the streets, a significant number of the most economically vulnerable cafeteros had already lost their land. These former growers became full-time workers on the large estates, or urban dwellers seeking employment in the informal sectors of the region's cities. In its efforts to re-instate the status quo ante, the UCN ignored the demands of other possible constituencies who might have been enlisted in the struggle against liberalization. These include agricultural workers who sought more far-reaching labor legislation, urban slum dwellers who demanded more affordable housing and public services, and those calling for national agrarian reform to redistribute land to the most vulnerable segments of the agrarian population, including Afro-Colombians, indigenous groups, and women (Hylton 2006).

The possibility of mobilizing around these issues was not theoretical. During the 1990s a number of new social movements had emerged throughout Colombia in support of these goals, and it would have been possible for the UCN to pursue alliances with some of these groups. However, as we have shown, the cafeteros of Viejo Caldas enjoyed a unique status within the political economy of Colombia, as both the protagonists and the beneficiaries of a long struggle for land reform, which dated from the foundations of the Colombian coffee economy in the $19^{\text {th }}$ century and culminated in the passage of Land Law 200 in 1936. Although the window of reform opened by Land Law 200 was brief, it was sufficient to create a smallholding sector of producers, who, over time, shifted from a mix of subsistence and cash crops to a more or less decisive dependence on coffee. This commitment to intensive coffee cultivation was buttressed by a parastatal coffee sector, headed by Fedecafé, which was the lynchpin of a national developmentalist project that rested on Colombia's participation in a regulated world coffee market. When radical challenges to the hegemony of that project emerged from other sectors, particularly the peasant and agricultural workers' movement of the 1960s, the student and urban civic movements of the 1970s, and the guerrilla movements in the 1980s, the cafeteros of Viejo 
Caldas remained steadfast supporters of the traditional political establishment, comprised of the Liberal and Conservative parties, even when these governments implemented repressive measures against these movements. And yet throughout this period, even as the smallholders remained, for the most part, loyal to the political establishment in the face of popular challenges to its rule, the geopolitical and political-economic foundations of the developmentalist project were being undermined, a process that was crystallized in the 1989 abrogation of the International Coffee Agreement. What followed was a period of sustained crisis during which efforts to mobilize in defense of producer livelihoods co-existed alongside dynamics of differentiation (i.e. increasing land concentration) and displacement (i.e. former smallholders turning to wage work or informality).

\section{CONCLUSION}

In this article we have argued that the consequences of world market liberalization for Colombia's farmers resemble the dynamic of dispossession that David Harvey describes as a central mode of accumulation in the neoliberal era. According to the Polanyian analytic described earlier, the effort to create a market society that is global in scope is calling forth counter-movements to resist the threat it poses to society. Advocates of this view expect that among such struggles, the most auspicious for challenging neoliberalism will be those that focus on the commodification of livelihoods and the privatization of resources. While the search for Polanyian counter-movements against the commodification of land, labor, and nature has produced celebratory accounts of flagship movements such as the MST, Via Campesina, or the EZLN, the analysis we have offered here raises a number of questions about how the UCN, as a different kind of agrarian struggle, should be interpreted. First, while Polanyi saw countermovements as organic efforts to re-embed the market in society, Polanyi's conceptualization of society as a constellation of different social forces was underdeveloped, as Burawoy (2010) has pointed out. The UCN was a movement representing a particular segment of rural producers, and the vision of an embedded market that it articulated was one that rested on an exclusionary developmentalist compromise. As demonstrated above, the class formation of the cafeteros was premised upon the establishment of a hegemonic political pact that stunted the mobilization of social groups and classes outside of it. In this sense, the "stable" class formation of the cafeteros was part and parcel of the "marginalized" class formation of those excluded groups and classes. And given the staunchly developmentalist political imaginary of the cafeteros, there is no indication that a return to a regulated/embedded coffee market would generate a dynamic any more inclusive than that of the past.

Second, interest in the re-embedding potential of counter-movements should not gloss over the very real social transformations that have been wrought by the movement towards neoliberalism. In the case of Viejo Caldas, we saw that the liberalization of the coffee market has given rise to a rapid concentration of land, the proletarianization of large sectors of the coffee labor force, and the growth of a new class of urban informal and illegal workers. Whatever forms of resistance are to confront the commodifying forces of neoliberalism, they will emerge from a social landscape that has already been altered by the disorganization and displacement of the cafeteros, whose historical formation as a class of smallholder producers we have analyzed here.

The transformations wrought by neoliberalism extend beyond the coffee fields of Viejo Caldas. Indeed, any evaluation of the UCN's potential as a movement to re-embed the market must confront the fundamental changes that have occurred in the geopolitics of the world coffee 


\section{JOURNAL OF WORLD-SYSTEMS RESEARCH}

sector over the last decades. As we have argued, the developmentalist pact between Fedecafé and the cafeteros of Viejo Caldas was premised upon the perpetuation of the International Coffee Agreement's pricing and quota system. Although one could interpret the ICAs as a kind of protective countermovement to regulate and thus re-embed the market in coffee-producing societies, it is worth pointing out that the ICA began as a pact between the United States (the largest coffee importer) and the largest coffee-exporting countries (Brazil, Colombia, Costa Rica, among others) in order to ensure U.S. hemispheric influence over the region As a regulatory mechanism, it excluded many coffee producing-exporting countries from the benefits of the pricing and quota system that the agreements established, while perpetuating the unequal distribution of profits for those countries that did participate in it. But even assuming that the reregulation of the coffee market by a new ICA would help at least some producers, such an outcome is extremely unlikely, precisely because the global conditions that gave rise to this form of regulation have fundamentally changed.

While we understand the appeal of the Polanyian analytic as a heuristic for interpreting the great transformation of post-Fordist neoliberalism, we want to conclude by calling for studies of the current conjuncture that draw on the tools and insights of world historical sociology in order to show how (and whether) this transformation is occurring in particular places, and with what consequences. In this article, we have demonstrated how a class of coffee-producing smallholders was formed in Viejo Caldas through a century long encounter with the Colombian state and the world coffee market. Although the UNC was formed in the 1990s to protest the liberalization of the global coffee market, the demands that it articulated were an extension of that process. Our goal, in tracing the trajectory of the cafeteros over the longue durée, has been to suggest that while dispossession by accumulation may be a defining feature of the neoliberal era

as Harvey and others have argued, the extent to which it is challenged by alternative visions of the future will depend on the political imaginaries of those confronting it. 
APPENDIX: MAP OF VIEJO CALDAS, COLOMBIA

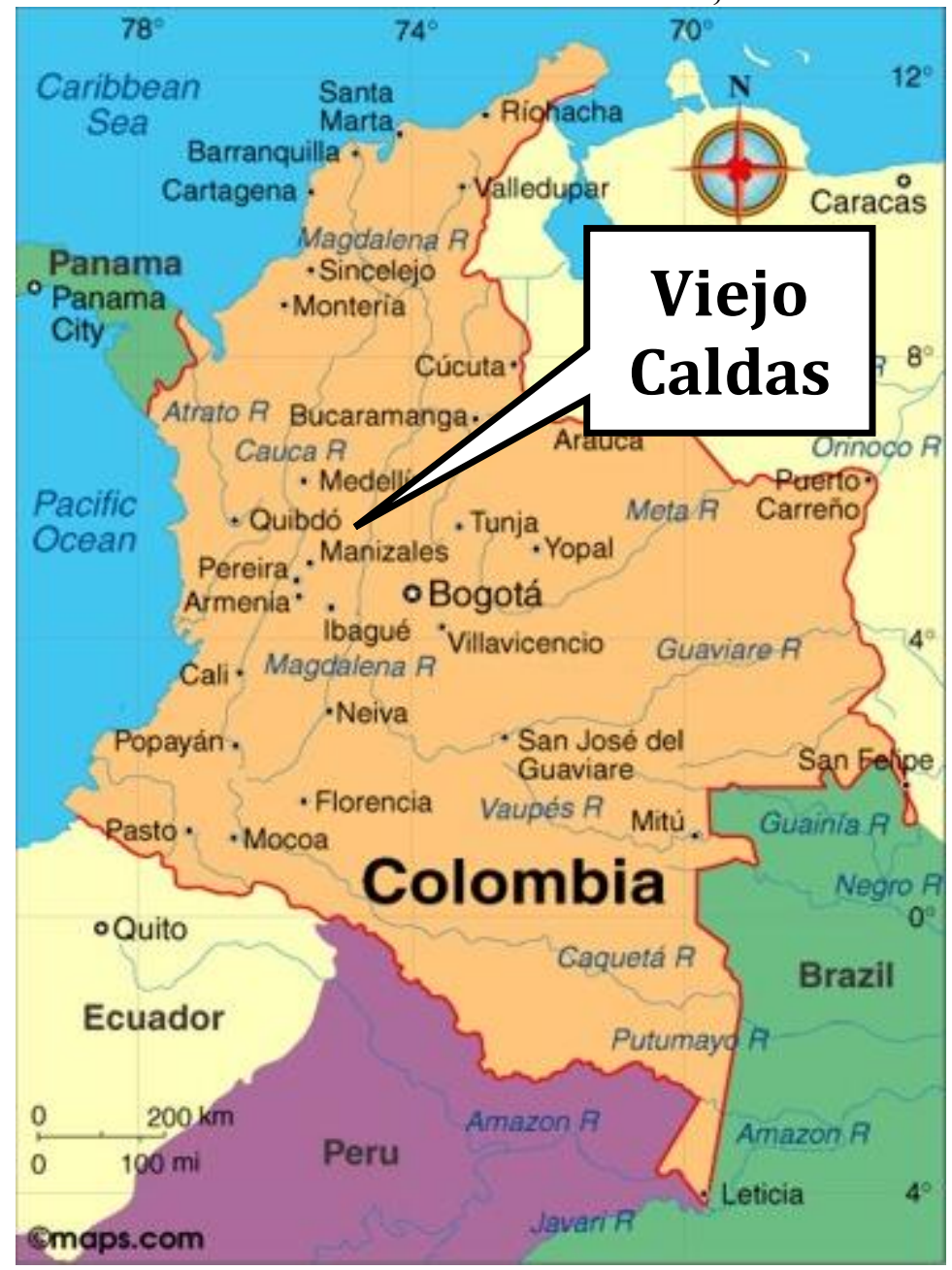




\section{REFERENCES}

Akram-Lodhi, A. Haroon. 2007. "Land, Markets, and Neoliberal Enclosure: An Agrarian Political Economy Perspective.” Third World Quarterly 28(8): 1437-1456.

Barchiesi, Franco. 2007. "Privatization and the Historical Trajectory of 'Social Movement Unionism': A Case Study of Municipal Workers in Johannesburg, South Africa." International Labor and Working-Class History 71(Spring): 50-69.

Bates, Robert H. 1997. Open-Economy Politics: The Political Economy of the World Coffee Trade. Princeton, NJ: Princeton University Press.

Bergquist, Charles. 1986. Labor in Latin America: comparative essays on Chile, Argentina, Venezuela and Colombia. Stanford, CA: Stanford University Press.

Burawoy, Michael. 2010. "From Polanyi to Pollyanna: The False Optimism of Global Labour Studies." Global Labour Journal 1(2): 301-313.

Christie, Keith. 1986. Oligarcas, Campesinos y Política en Colombia: Aspectos de la Historia Socio-política de la Frontera Antioqueña. Bogotá, Colombia: Universidad Nacional de Colombia.

Dunn, Bill. 2007. "Accumulation by Dispossession or Accumulation of Capital?: The Case of China." Journal of Australian Political Economy, 1(60): 5-27.

Evans, Peter. 2008. "Is an Alternative Globalization Possible?" Politics and Society 36(2): 271305.

Hart, Gillian. 2006. "Denaturalizing Dispossession: Critical Ethnography in the Age of Resurgent Imperialism” Antipode 38(6): 977-1004.

Harvey, Neil. 1998. The Chiapas Rebellion: The Struggle for Land and Democracy. Durham, NC: Duke University Press.

Harvey, David. 2003. The New Imperialism. Oxford, UK: Oxford University Press.

-----. 2007. "Neoliberalism as Creative Destruction." The ANNALS of the American Academy of Political and Social Science 610: 22-44.

Holt Gimenez, Eric and Annie Shattuck. 2011. "Food Crises, Food Regimes and Food Movements: Rumblings of reform or tides of transformation." Journal of Peasant Studies 38(1): 109-144.

Hough, Phillip A. 2007. "Trajectories of Hegemony and Domination in Colombia," Doctoral Thesis, Department of Sociology, The Johns Hopkins University, Baltimore, MD.

-----.. 2010. "Global Commodity Chains and the Spatial-Temporal Dimensions of Labor Control: Lessons from Colombia's Coffee and Banana Industries" The Journal of WorldSystems Research XVI(2): 123-161.

------. 2011a. "Guerrilla Insurgency as Organized Crime: Explaining the So-called 'Political Involution' of the Revolutionary Armed Forces of Colombia" Politics and Society. Forthcoming 39(3).

------. 2011b. "Hegemonic Projects and the Social Reproduction of the

Peasantry: Examining the National Federation of Coffee Growers and the Revolutionary Armed Forces of Colombia in World Historical Perspective." Review: The Journal of the Fernand Braudel Center. Forthcoming, XXXIII.

Hylton, Forrest. 2006. Evil Hour in Colombia. London: Verso Press.

Jiménez, Michael F. 1995a. "From plantation to cup: coffee and capitalism in the United States, 
1830-1930." Pp. 38-64 in Coffee, Society, and Power in Latin America, edited by William Roseberry, Lowell Gudmundson, and Mario Samper Kutschbach. Baltimore, MD: The Johns Hopkins University Press.

-----. 1995b. "At the Banquet of Civilization: The Limits of Planter Hegemony in EarlyTwentieth-Century Colombia." Pp. 262-294 in Coffee, Society, and Power in Latin America, edited by William Roseberry, Lowell Gudmundson, and Mario Samper Kutschbach.. Baltimore, MD: The Johns Hopkins University Press.

Krasner, Stephen D. 1973. "Business Government Relations: The Case of the International Coffee Agreement." International Organization 27: 495-516.

Lee, Ching Kwan. 2007. Against the Law: Labor Protests in China's Rustbelt and Sunbelt. Berkeley, CA: University of California Press.

LeGrand, Catherine. 1984. "Labor Acquisition and Social Conflict on the Colombian Frontier, 1850-1936." Journal of Latin American Studies 16: 27-49.

London, Christopher. 1999. "Desarrollismo, Democracia y la Crisis Cafetera: Una Interpretación Cultural.” Pp. 95-149 in Conflictos Regionales: La Crisis del Eje Cafetero, edited by Gonzalo Sánchez, Jorge Enrique Robledo Castillo, Absalón Machado, Manuel E. López, Christopher London. Bogotá: IEPRI \& FESCOL.

Machado, Absalón. 1977. El Café: De la Aparcería al Capitalismo. Bogotá, Colombia: Punta de Lanza.

McMichael, Philip. 2006. "Peasant Prospects in the Neoliberal Age." New Political Economy 11(3): 407-418.

-----. 2008. "Peasants Make Their Own History, But Not Just as They Please..." Journal of Agrarian Change 8(2-3): 205-228.

Mittelman, James. 1998. "Globalisation and Environmental Resistance Politics." Third World Quarterly 15(5): 847-872.

Munck, Ronaldo. 2002. "Globalization and Democracy: A New Great Transformation." The ANNALS of the American Academy of Political and Social Science 581: 10-21.

Ortiz, Sutti. 1999. Harvesting Coffee, Bargaining Wages: Rural Labor Markets in Colombia, 1975-1990. Ann Arbor, MI: University of Michigan Press.

Oxfam. 2002. Mugged: Poverty in your Coffee Cup. Washington, D.C.: Oxfam.

Polanyi, Karl. [1944] 1966. The Great Transformation. Boston: Beacon Press.

Ramírez, Luis Fernando et al. 2002. El Café, Capital Social Estratégico: Informe Final, Comisión de Ajuste de la Institucionalidad Cafetera. Bogotá, Colombia: Ministerio de Hacienda y Crédito Público, Gobernación de Colombia.

Rettberg, Angelika 2010. "Global Markets, Local Conflict: Violence in the Colombian Coffee Region after the Breakdown of the International Coffee Agreement." Latin American Perspectives 37: 111-132.

Robledo, Jorge Enrique. 1998. El Café en Colombia: Un Análisis Independiente. Bogotá, Colombia: El Áncora Editores.

Sánchez, Gonzalo, 2001. "Introduction: Problems of Violence, Prospects for Peace." Pp. 1-38 in Violence in Colombia, 1990-2000: Waging War and Negotiating Peace, edited by Charles Bergquist, Ricardo Peñaranda, Gonzalo Sánchez. Wilmington, DE: Scholarly Resources Press.

Silver, Beverly. 2003. Forces of Labor: Workers' Movements and Globalization since 1870. Cambridge, UK: Cambridge University Press.

Silver, Beverly and Giovanni Arrighi. 2003. "Polanyi’s Double Movement: The Belle Époques 
of British and U.S. Hegemony Compared." Politics and Society 31(2): 325-355.

Smith, Tony. 2003. "Difficult Times for Coffee Industry." World Business, November 25.

Spronk, S. and J. Webber. 2007. "Struggles against Accumulation by Dispossession in Bolivia: The Political Economy of Natural Resource Contention." Latin American Perspectives 34(2): 31-47.

Swyngedouw, Erik. 2005. "Dispossessing H20: The Contested Terrain of Water Privatization." Capitalism, Nature, Socialism 16(1): 81-98.

Talbot, John. 2004. Grounds for Agreement: The Political Economy of the Coffee Commodity Chain. New York: Rowman \& Littlefield Publishers, Inc.

Vallecilla Gordillo, Jaime. 2001. Café y Crecimiento Económico Regional: El Antigua Caldas. Manizales, Colombia: Universidad de Caldas.

Walker, Kathy LeMons. 2008. "From Covert to Overt: Everyday Peasant Politics in China and the Implications for Transnational Agrarian Movements." Journal of Agrarian Change 8(2-3): 462-488.

World Bank. 2002. "Estudio del Sector Cafetero en Colombia." Ensayos sobre la Economía Cafetera. Fedecafé 15: 18.

Zamosc, Leon. 1986. The Agrarian Question and the Peasant Movement in Colombia: Struggles of the National Peasant Association (1967-1981). Cambridge \& New York: Cambridge University Press. 